$$
\begin{gathered}
\text { 부모-자녀 간의 의사소통, 자아정체감, 청소년의 } \\
\text { 학교적응 간의 관계구조† }
\end{gathered}
$$

\title{
Structural Relationships Among Parent-Adolescent Communication, Ego-Identity, and School Adjustment
}

\author{
이지민* \\ 영남대학교 가족주거학과
}

Lee, Ji-Min

Dept. of Family and Housing Studies, Yeungnam University

\begin{abstract}
The purpose of this study was twofold: One was to investigate the structural relationships among communication with father and mother, ego-identity, and school adjustment. The other was to test the structural equivalence among researched variables between middle and high school samples. The subjects were 419 sophomores of middle and high schools. The major findings were as follows. 1) Communication with the father had direct and indirect effects on adolescents' school adjustment, while communication with the mother had only an indirect effect on school adjustment. 2) Ego-identity had a direct effect on school adjustment, and mediated the effects of communication with father and mother in school adjustment. 3) Multiple-group analysis revealed that middle and high school groups had the same structural relationships, but had different regression weights.
\end{abstract}

Keywords : adolescent, communication with father, communication with mother, ego-identity, school adjustment

\section{I. 서론}

학교는 청소년들이 새로운 지식과 기술을 습득하고 미 래 사회의 구성원으로서 생활하는데 필요한 규범과 역할 을 배우는 기관으로서 청소년들의 성장발달에 중요한 역 할을 하는 장소이다. 특히 우리나라 청소년들은 활동시 간의 대부분을 학교에서 보내므로 학교에서의 적응은 청 소년들의 심리 사회적 건강을 이해하는데 중요한 지표가 된다. 또한 청소년기는 성인기의 전단계로서 청소년기의 학교적응은 성인기의 건전한 발달 및 적응에 커다란 영
향을 미치게 된다.

그러나 우리나라 청소년들의 학교생활에 대한 적응과 만족도에 대한 연구에 의하면, 많은 청소년들이 적성과 수준에 맞지 않는 수업이나 엄격한 교칙, 교사나 학생들 간의 대인관계나 경쟁 등으로 학교생활에 흥미를 느끼지 못하고 힘들어 하는 것으로 나타났다(김수진 외, 2004; 류경희, 2003). 또한 최근 학교에 적응하지 못하고 학업 을 중단한 청소년들이 매년 6 7만 발생하고 있으며 이 는 전체 학령기 인구의 $2.3 \%$ 에 달하여 청소년들의 학교 부적응 현상이 심화되고 있음을 알 수 있다(교육통계연

† 이 연구는 2007년 영남대학교 학술연구조성에 의한 것임.

* Corresponding author: Lee, Ji-Min

Tel: 053-810-2866

E-mail: 1jimin@ynu.ac.kr 
보, 2006). 청소년들의 학교 부적응은 청소년 비행이나 범죄로 이어질 가능성이 높으며 이는 청소년 개개인의 미래뿐만 아니라 국가적 차원에서도 커다란 손실을 초래 하게 된다(김광수, 2002; 김여진, 2006). 따라서 청소년 들이 학교생활에 잘 적응하지 못하는 원인을 파악하고 학교 부적응을 예방할 수 있는 대책을 마련하는 것이 시 급하다고 할 수 있다.

학교적응이란 학교생활에 대해 긍정적인 태도를 가지 며 바람직한 사회적, 정서적 행동을 하는 정도를 의미한 다(문은식, 2004; 민하영, 권기남, 2004). 학교적응은 단 일 개념이라기 보다는 복합적 개념으로 연구자에 따라 학교에 대한 흥미, 학업성취에 대한 태도, 학교규범 준수 영역(박현선, 1998)이나 교사관계, 교우관계, 학교수업 및 학교규칙에 대한 적응 영역(배숙진, 1998)으로 개념 화된다. 학교적응에 영향을 미치는 요인들로는 여러 가 지가 있을 수 있으나, 청소년들의 건강한 발달과 적응이 가족과의 상호작용이나 관계 형성에 기초한다는 점과 청 소년들을 문제행동이나 부적응 상황으로 유도하는 일차 적인 원인이 가족인 경우가 많다는 점을 고려할 때, 학교 적응에 영향을 미치는 중요한 변인으로서 가족관련 변인 에 대한 심도 있는 탐색이 필요할 것으로 보여진다.

학교적응에 영향을 미치는 가족관련 요인으로 가족의 구조적인 측면, 기능적인 측면, 관계적인 측면 등 여러 요 인들이 연구되어 왔으며(류경희 2003; 배숙진, 1998; 정 유진, 1999; Armsden \& Greenberg, 1987; Kurdek \& Sinclair, 1988), 이들 요인들 중에서 부모-자녀 간의 의 사소통은 청소년의 학교적응에 지속적인 영향을 주는 요 인으로 지적되어 왔다(이경님, 2003; 홍연란, 2000). 청 소년기에는 자율성과 독립에 대한 옥구가 강해짐에 따라 부모와의 관계에서 다양한 갈등과 대립을 경험하는 한편, 부모의 관심과 이해 및 대화를 절실히 요구하기도 한다 (김여진, 2006; Collins \& Repinski, 1994; Hill \& Holmbeck, 1986). 특히 청소년기 부모-자녀 간의 의사 소통은 역할조망과 도덕성 발달 등 청소년들의 인성이나 행동 발달과 성숙에 결정적인 영향을 미치며, 의사소통을 통한 부모-자녀 간의 인간관계는 교사나 또래와의 관계뿐 만 아니라 학교적응의 전반적인 측면에 중요한 영향을 미 치는 것으로 나타났다(남민숙, 2006; 최재숙, 2001).

부모-청소년 자녀 간의 의사소통과 학교적응에 관한 선행연구에 의하면, 부모가 청소년 자녀에 대해 애정과 신뢰를 가지고 개방적으로 의사소통을 하는 경우 청소년 들은 학교에 더 잘 적응하는 것으로 나타났다(김지현,
1996; 백경숙, 권용신, 2004). 부모-청소년 자녀 간의 개 방적 의사소통은 가족의 응집성과 적응성이 기능적인 수 준이 되도록 도와주는 의사소통 유형으로 부모와 청소년 자녀 간의 상호작용에서 서로 억압하지 않고 자유롭게 감정이나 의사를 표현하는 의사소통을 의미한다(Banes \& Olson, 1982). 이러한 개방적인 의사소통은 부모-자 녀 간의 솔직하고 자유로운 의사교환을 가능하게 하고 서로간의 이해와 만족도를 항상시키는 데 중요한 역할을 한다. 또한 개방적인 의사소통을 통해 부모-자녀 간의 긴 장과 갈등이 해소되며 학교적응을 포함한 전반적인 생활 적응의 향상이 이루어질 수 있다. 반면, 부모와의 의사소 통이 단절되거나 부족한 경우, 그리고 역기능적인 의사 소통을 하는 경우 비행, 인터넷 중독, 가출 등의 문제행 동이 유발될 가능성이 높으며 학교적응에도 부정적인 영 향을 미치는 것으로 나타났다(문영숙, 2008; 박지현, 2003; 이경님, 2003; 이경님, 하연미, 2004).

청소년기 동안 부모-자녀간의 긍정적이고 개방적인 의 사소통이 청소년들의 건강한 성장 발달뿐 아니라 학교적 응에 매우 중요함에도 불구하고 최근 부모-자녀 간의 의 사소통 기회와 관심은 감소하는 경향이 있으며 대화시간 도 많이 부족한 실정이다. 그나마 의사소통 기회가 있더 라도 일방적 지시나 훈계, 비난, 비판 등의 비효과적인 방법으로 대화하는 경우가 많으며, 이러한 의사소통 방 법은 부모와 청소년 자녀 간의 갈등을 심화시키는 원인 이 될 수 있으며 더 나아가 청소년의 학교적응에 부정적 인 영향을 미칠 수 있다. 따라서 부모-자녀 간의 개방적 인 의사소통을 항상시킬 수 있는 방안에 대한 연구가 필 요하리라 생각되어진다. 또한 대부분의 선행연구에서는 주로 어머니와 청소년의 의사소통과 학교적응에 관한 연 구들이 주를 이루어져 왔다. 그러나 최근 자녀양육에 있 어 아버지 역할의 중요성이 부각됨에 따라 아버지와의 의사소통이 청소년의 학교적응에 미치는 영향에 대한 연 구도 지속적으로 이루어지고 있으나(백경숙, 권용신, 2004; 조윤미, 이숙, 2008) 양적으로 부족한 실정이므로 이에 대한 연구가 더 이루어질 필요가 있으리라 생각되 어진다.

가족관련 변인과 더불어 긍정적인 자아정체감 형성은 청소년기에 이루어야 할 발달과업으로서 학교적응에 중 요한 영향을 미치는 요인으로 지적되고 있다(이현림, 천 미숙, 2003; 조미란, 1989). 자아정체감은 자신의 존재에 대한 일관적이고 안정적인 생각으로(Erikson, 1968), 개 인의 내적 탐색과 사회적 상호작용을 통해 발달한다(민 
하영, 권기남, 2004). 청소년기 동안 '나는 누구이며 미 래에 무엇을 할 수 있는가에 대한 탐색적 물음에 답하려 는 노력을 하게 되며, 자아정체감 형성을 위한 이러한 노 력은 앞으로 자신이 나아가야 할 미래의 전망을 제시해 준다.

청소년기 동안 긍정적인 자아정체감이 형성되면 자신 을 있는 그대로 인정하고 수용하여 정서적으로 안정되며 인생의 목표를 설정하고 이를 실천해 나갈 수 있는 구체 적인 노력들을 하게 된다. 또한 주위의 사람들과 원만하 고 안정적인 대인관계를 유지하게 된다. 반면, 자아정체 감이 부정적으로 형성되거나 혼미하게 되면 자신을 부정 하고 무능한 자신에 대해 열등감을 느끼며 인생의 목표 에 대한 방향을 상실하게 된다. 타인을 불신하며 친밀하 고 긍정적인 대인관계를 형성하는 데에도 어려움을 겪게 된다. 이처럼 자아정체감의 형성 여부는 청소년 개개인 의 건전한 발달에도 중요한 영향을 미칠 뿐 아니라 청소 년들이 미래를 준비하기 위해 대부분의 시간을 보내는 학교적응에도 큰 영향을 미칠 것으로 생각된다.

자아정체감과 학교적응에 관한 선행연구를 살펴보면, 긍정적인 자아정체감을 형성한 청소년들은 또래와의 관 계에서 안정적이며 학업 성취도도 높은 것으로 나타 난 반면, 부정적인 자아정체감을 형성한 청소년들은 교사나 또래 관계에서 부적응을 나타내며, 학교생활에 흥미를 느끼지 못하는 것으로 나타났다(박영란, 2002; 현희순, 김양순, 1999; Erath et al., 2008). 또한 자아정체감이 높은 청소년들은 자아정체감이 낮은 청소년들보다 학교 생활에서 스트레스나 문제 상황에 직면할 때, 보다 적극 적으로 대처를 하여 자신들의 학교생활 전략을 스스로 모색해 나가는 경향이 있는 것으로 나타났다(이종연, 이 재신, 2000). 청소년기의 중요한 과업으로써 자아정체감 과 학교적응의 관련성을 생각해 볼 때, 최근 심각해지고 있는 학교 부적응을 줄일 수 있는 해결책의 한 방안으로 청소년들의 자아정체감 항상을 면밀히 고려해 볼 필요가 있다.

이러한 연구들에 기초해서 볼 때, 청소년기 건강한 적 응의 기초가 되는 가족에서의 부모-자녀 간의 의사소통 과 이 시기의 중요한 발달과업인 자아정체감은 청소년들 의 학교적응에 영향을 미치는 주된 요인이며 청소년들의 학교적응을 향상시키기 위해서는 일차적으로 부모-자녀 간의 개방적인 의사소통을 증진시키고 긍정적인 자아정 체감을 항상시킬 수 있도록 해야 함을 알 수 있다. 그러
나 부모자녀 간의 의사소통과 자아정체감이 학교적응에 미치는 영향은 각각 연구되어져 왔으며 이 요인들을 동 시에 다룬 연구는 많지 않다. 또한 대부분의 연구들은 학 교적응에 영향을 미치는 이들 변인들의 직접적인 효과만 을 살펴보았을 뿐 부모-자녀 간의 의사소통과 자아정체 감, 학교적응 간의 구조적인 관계를 분석한 연구는 많지 않은 실정이다. 최근 부모의 의사소통이나 양육행동이 청소년의 자아존중감이나 자기효능감 등의 자아관련 변 인을 통해 간접적으로 학교적응에 영향을 미친다는 결과 들이 보고되고 있다(이경님, 2003; 백경미 외, 2008). 이 러한 결과들로 미루어 볼 때, 부모-자녀간의 의사소통은 학교적응에 직접적인 영향을 미칠 뿐만 아니라 청소년의 자아정체감 형성을 통해 간접적으로도 영향을 미칠 것으 로 가정할 수 있다.

선행연구에 의하면 청소년의 학교적응은 중학생과 고 등학생에 따라 다소 차이가 있으며(구자경 외, 2001; 김 광수, 2002; 유윤희, 1994; 이진숙, 정혜정, 2004), 이에 따라 학교적응에 영향을 미치는 변인들의 직접, 간접 효 과들도 중학생, 고등학생 집단에 따라 차이가 있으리라 생각되어진다. 학년에 올라감에 따라 학교적응에 영향을 미치는 변인들의 효과가 어떻게 차이 나는가를 살펴보는 것은 청소년의 학교적응을 지도하는데 중요한 자료가 될 것이다. 이에 본 연구에서는 청소년의 학교적응에 영향 을 미치는 변인으로 아버지와 어머니와의 의사소통과 청 소년의 자아정체감을 선정하고 이들 변인들 간의 관계를 구조방정식 모형으로 설정하여 직접적, 간접적 효과를 살펴보고자 한다. 또한 본 연구에서 채택된 구조방정식 모형이 중학생과 고등학생 집단에 동일하게 적용될 수 있는지에 대해 살펴보고자 한다. 본 연구 목적에 따른 연 구 모형은 [그림 1]과 같다.

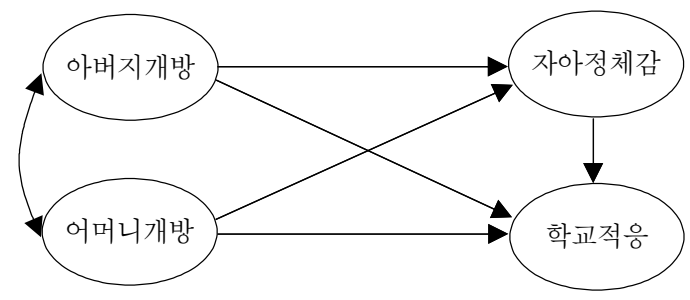

[그림 1] 청소년의 학교적응과 관련 변인들 간의 가설적 연구모형 
II. 연구방법

1. 연구대상 및 절차

본 연구의 대상은 대전 지역에 거주하는 중학교 2 학년 212 명과 고등학교 2학년 207명으로 총 419명이었다<표 $1>$. 중학생의 평균 연령은 13.7 세이었으며 고등학생의 평균 연령은 16.6 세 이었다.

<표 1> 연구 대상

\begin{tabular}{c|c|c|c}
\hline 구분 & 중학교 & 고등학교 & 전체 \\
\hline 남학생 & 109 & 106 & 215 \\
여학생 & 103 & 101 & 204 \\
\hline 전체 & 212 & 207 & 419 \\
\hline
\end{tabular}

\section{2. 측정도구}

1) 부모-자녀 의사소통

부모-자녀 간의 의사소통은 Barnes와 Olson(1982)이 제작한 부모-청소년 자녀 간의 의사소통 척도(Parent-

Adolescent Communication Inventory)를 민혜영(1990) 이 번역한 것을 사용하였다. 원척도는 의사소통의 하위영 역으로 개방형 의사소통과 문제형 의사소통으로 구분되 어 각 10 문항씩 모두 20 문항으로 구성되어 있으며 각 문 항은 아버지와 어머니에게 동일한 내용으로 구성되었다. 본 연구에서는 아버지와의 개방형 의사소통과 어머니와 의 개방형 의사소통만을 사용하였으며 문항꾸러미 방법 으로 아버지 개방-1과 아버지 개방2, 어머니 개방-1과 어머 니 개방 2 를 지표변수로 설정하여 사용하였다. 문항꾸러 미 방법(item parceling method)은 주어진 척도하의 문 항들을 두 개 또는 세 개의 꾸러미로 묶어 새로운 지표변 수를 만드는 방법이다(문수백, 2009). 문항꾸러미 방법을 통해 척도에 포함된 문항을 두 개 또는 세 개의 꾸러미 속에 무작위로 배치할 경우 통계적으로 각 꾸러미 속에 배치된 문항의 모든 특성(문항신뢰도 및 문항타당도 등) 이 골고루 분배될 것으로 기대할 수 있다.

부모-자녀간의 개방형 의사소통에 관한 문항으로는 '나는 아버지(어머니)께 주저함 없이 내 주장을 이야기 할 수 있다', ‘아버지(어머니)와 함께 문제를 의논하기가 쉽다' 등이다. 각 문항의 응답 방식은 '전혀 그렇지 않다 (1)'에서 '매우 그렇다(5)'의 5점 척도로 측정되었으며
점수가 높을수록 부모-자녀 간의 의사소통이 긍정적이고 개방적임을 의미한다. 각 요인의 Cronbach's $\alpha$ 는 아버지 개방 1 과 아버지 개방 2 는 각각 $.82, .83$ 이었으며 어머니 개방 1 과 어머니 개방 2 는 $.80, .79$ 이었다.

\section{2) 자아정체감}

청소년의 자아정체감은 박아청(1996)이 개발한 '한국 형 자아정체감 검사'를 이승국(1999)이 일부 수정 - 보완 한 척도를 사용하여 측정하였다. 48 개의 문항을 요인분 석하여 공통성이 낮은 4 문항을 제외하고 다시 요인분석 한 결과 6요인(미래확신성, 자기수용성, 친밀성, 주체성, 주도성, 목표지항성)이 추출되었다. 청소년의 자아정체감 에 관한 문항으로는 '내가 무엇이 되고 싶은가를 분명히 알고 있다', ‘나는 누가 시키지 않아도 내 일은 내가 알아 서 한다' 등이다. 각 문항은 '전혀 그렇지 않다(1)'에서 '매우 그렇다(5)'까지의 5점 척도로 측정되었으며 부정 적인 내용의 문항은 역산하였다. 각 요인별로 점수가 높 을수록 자아정체감이 높은 것을 의미한다. 각 요인의 Cronbach's $\alpha$ 는 미래확신성이 .92, 자기수용성이 .89, 친밀성이 .83 , 주체성이 .80 , 주도성이 .82 , 그리고 목표 지향성이 .78 이었다.

\section{3) 학교적응}

청소년의 학교적응은 박현선(1998)의 학교적응 유연 성 검사를 수정 - 보완하여 사용하였다. 22 개의 문항을 요인분석하여 공통성이 낮은 6 문항을 제외하고 다시 요 인분석 한 결과 3 요인(학교규범 준수, 학교생활에 대한 흥미, 학업 및 성적에 대한 태도)이 추출되었다. 학교적 응 관한 문항으로는 '학교의 규범을 준수한다', '학교생 활이 즐겁다', ‘수업시간에 나는 도움이 되는 것을 배운 다고 생각한다' 등이다. 각 문항은 '전혀 그렇지 않다(1)' 에서 '매우 그렇다(5)'까지의 5 점 척도로 측정되었으며 부정적인 내용의 문항은 역산하였다. 각 요인별로 점수 가 높을수록 학교 적응이 높은 것을 의미한다. 각 요인의 Cronbach's $\alpha$ 는 학교규범 준수가 .78, 학교생활에 대한 흥미가 .77, 학업 및 성적에 대한 태도가 .74 이었다.

\section{3. 분석방법}

청소년 학교적응의 원인변인으로 설정한 아버지와의 개방형 의사소통과 어머니와의 개방형 의사소통, 자아정 
체감간의 직 · 간접효과를 분석하기 위해 단일척도의 경 우 문항꾸러미 방법을 이용하여 각 잠재변수별로 두 개 의 지표변수를 설정하였다.

아버지와의 개방형 의사소통의 경우 문항꾸러미 방법 에 따라 전체 문항을 두 개의 꾸러미 집단으로 분류한 다 음 아버지 개방 1 과 아버지 개방2의 두 개의 지표변수로 설정하였다. 어머니와의 개방형 의사소통도 같은 방법으 로 어머니 개방1과 어머니 개방2의 두 개의 지표변수를 설정하였다. 아버지 개방 1 과 개방 2 , 어머니 개방 1 과 개 방2의 지표변수를 통해 아버지 개방형 의사소통과 어머 니 개방형 의사소통을 측정하였다. 그리고 자아정체감을 측정하기위해 미래확신성, 자기수용성, 친밀성, 주체성, 주도성, 목표지향성을 지표변수로 설정하였으며 학교적 응을 측정하기 위해 학교규범준수, 학교생활에 대한 흥 미, 학업 및 성적에 대한 태도를 지표변수로 설정하였다. 그리고 모델추정 조건에 따라 단위부하량(unit loading identification) 고정법에 따라 잠재변수에 척도를 부여한 다음 [그림 2]와 같이 통계적 모델을 설정하였다.

설정된 통계적 모델의 추정 방법을 결정하기 위해 $\mathrm{AMOS17.0}$ 의 다변인정규분포성 검증 절차를 통해 구조 방정식모델하의 13 개 측정변수들에 대한 다변인정규분 포성을 검증한 결과, 단변인별 왜도와 첨도 모두에 있어 서 정규분포의 조건을 만족한 것으로 나타났을 뿐만 아 니라 다변인정규분포성 가정 역시 충족된 것으로 나타났 기 때문에 AMOS17.0의 최대우도추정법(Maximum Likelihood Estimation)을 적용하여 통계적 모델의 부합 도와 모수치를 추정하였다. 자료의 신뢰도와 상관관계,
기술적 통계를 위해서는 SPSS/WIN 프로그램을 이용하 여 분석하였다.

모델부합도는 부합도지수 $\chi^{2}$ 값, RMSEA, CFI, TLI를 통해 평가하였다. 그리고 모델하의 변인들간의 직접효과 는 유의수준 .01에서 통계적 유의성을 검증하였으며 간 접효과 역시 AMOS17.0의 Bootstrapping 절차를 사용 하여 분석한 다음 유의수준 .01에서 통계적 유의성을 검 증하였다. 동일성 검증은 내재된 모형(nested model)들 에 대한 위계적인 분석을 통해 이루어졌다.

\section{III. 연구결과}

\section{1. 측정변인간의 상관관계 및 기술 통계치}

통계적 모델하의 측정변인들간의 상관행렬 및 각 측정 변인들의 평균 및 표준편차를 추정한 결과는 <표 $2>$ 와 같다.

\section{2. 연구모델의 분석 결과}

1) 측정모델의 부합도 평가

연구모델인 구조회귀모델의 모델추정가능성과 부합도 를 검증하기 전에 2단계 모델추정가능성 확인절차(문수 백, 2009)에 따라 아래의 [그림 3]과 [그림 4]와 같이 측 정모델과 구조모델을 분리하여 설정한 다음 설정된 측정 모델과 구조모델의 모델추정 가능성을 검토하였다. 측정

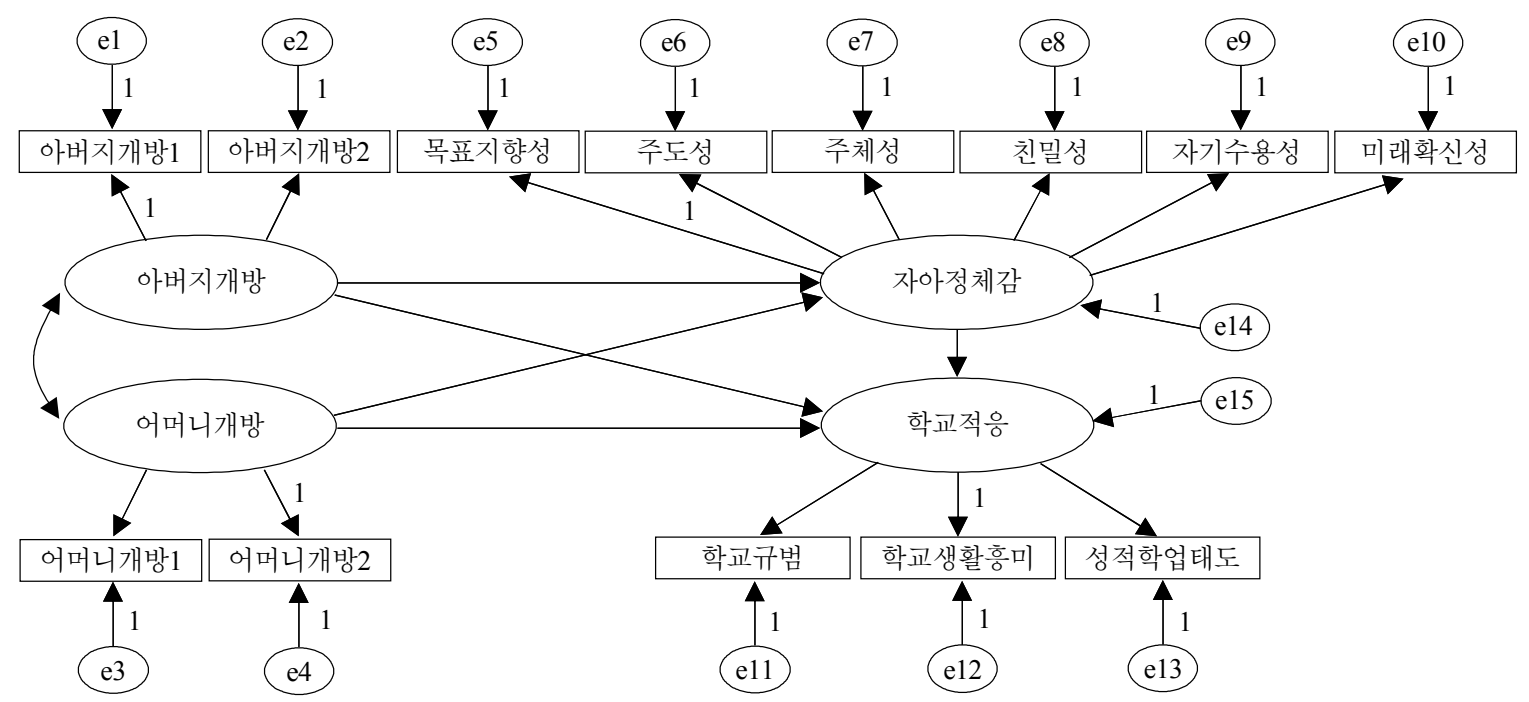

[그림 2] 통계적 모델 
<표 2> 측정변인간의 상관행렬 및 평균, 표준편차

\begin{tabular}{|c|c|c|c|c|c|c|c|c|c|c|c|c|c|c|}
\hline 중 & 고 & 1 & 2 & 3 & 43 & 5 & 6 & 7 & 8 & 9 & 10 & 11 & 12 & 13 \\
\hline & 1 & 1 & $.77 * *$ & $.36^{* *}$ & $.33^{* *}$ & .09 & $.22 * *$ & .07 & $.23^{* *}$ & .04 & .10 & .03 & $.19 * *$ & $.21 * *$ \\
\hline & 2 & $.78^{* *}$ & 1 & $.31 * *$ & $.41^{* *}$ & .11 & $.27 * *$ & .06 & $.24 * *$ & .02 & .08 & -.03 & $.15^{*}$ & $.20 * *$ \\
\hline & 3 & $.25 * *$ & $.35^{* *}$ & 1 & $.80^{* *}$ & .55 & $.32 * *$ & $.14^{*}$ & $.25^{* *}$ & .06 & $.14^{*}$ & .02 & .09 & .12 \\
\hline & 4 & $.23 * *$ & $.39 * *$ & $.77 * *$ & 1 & .07 & $.26^{* *}$ & .12 & $.21^{* *}$ & .04 & .09 & .02 & $.14^{*}$ & $.16^{*}$ \\
\hline & 5 & $.18^{* *}$ & $.20 * *$ & $.22 * *$ & $.29 * *$ & 1 & $.38 * *$ & $.27 * *$ & $.47 * *$ & $.27 * *$ & $.37 * *$ & $.17^{*}$ & $.24 * *$ & .13 \\
\hline & 6 & $.30 * *$ & $.27 * *$ & $.36^{* *}$ & $.37 * *$ & $.48^{* *}$ & 1 & $.34 * *$ & $.56^{* *}$ & $.33 * *$ & $.43^{* *}$ & $.17^{*}$ & $.44^{* *}$ & $.17^{* *}$ \\
\hline & 7 & $.27 * *$ & $.20 * *$ & $.16^{*}$ & $.14^{*}$ & $.22 * *$ & $.42 * *$ & 1 & $.44^{* *}$ & $.60 * *$ & $.38 * *$ & .05 & $.21^{* *}$ & .10 \\
\hline & 8 & $.29 * *$ & $.32 * *$ & $.35^{* *}$ & $.32 * *$ & $.40^{* *}$ & $.59^{* *}$ & $.27 * *$ & 1 & $.49 * *$ & $.64^{* *}$ & $.15^{*}$ & $.33^{* *}$ & $.38 * *$ \\
\hline & 9 & $.21 * *$ & $.14^{*}$ & $.24 * *$ & $.14 *$ & $.34^{* *}$ & $.53^{* *}$ & $.64 * *$ & $.47^{* *}$ & 1 & $.44^{* *}$ & -.02 & .06 & .08 \\
\hline & 10 & $.24 * *$ & $.26^{* *}$ & $.21^{* *}$ & $.22 * *$ & $.26^{* *}$ & $.41 * *$ & $.42 * *$ & $.51 * *$ & $.53 * *$ & 1 & .05 & $.28 * *$ & $.27 * *$ \\
\hline & 11 & .09 & .10 & $.27 * *$ & $.19^{* *}$ & $.14^{*}$ & $.29 * *$ & .02 & $.27 * *$ & $.17^{*}$ & $.16^{*}$ & 1 & $.39 * *$ & $.20^{* *}$ \\
\hline & 12 & $31^{* *}$ & $.33 * *$ & $.33^{* *}$ & $.33 * *$ & $.21^{* *}$ & $.42 * *$ & $.16^{*}$ & $.39 * *$ & $.21 * *$ & $.31^{* *}$ & $.53 * *$ & 1 & $.30^{* *}$ \\
\hline & 13 & $.28 * *$ & $.34 * *$ & $.20 * *$ & $.23^{* *}$ & $.24 * *$ & $.34 * *$ & .08 & $.51^{* *}$ & $.22 * *$ & $.37^{* *}$ & $.23 * *$ & $.42 * * *$ & 1 \\
\hline \multirow{2}{*}{ 중 } & $\mathrm{M}$ & 3.34 & 3.20 & 3.89 & 3.64 & 3.36 & 3.73 & 3.29 & 3.39 & 3.30 & 3.11 & 3.63 & 3.01 & 2.83 \\
\hline & SD & .79 & .79 & .73 & .77 & .86 & .76 & .75 & .63 & .67 & .76 & .50 & .56 & .58 \\
\hline \multirow{2}{*}{ 고 } & $\mathrm{M}$ & 3.22 & 3.11 & 3.97 & 3.73 & 3.37 & 3.87 & 3.23 & 3.36 & 3.28 & 2.92 & 3.44 & 2.67 & 2.76 \\
\hline & SD & .86 & .87 & .70 & .74 & 1.02 & .80 & .77 & .60 & .70 & .74 & .45 & .53 & .49 \\
\hline
\end{tabular}

${ }^{*} p<.05,{ }^{* *} p<.01$, 상관표의 대각선 왼쪽 아래는 중학생 자료이며, 오른쪽 위는 고등학생 자료임.

1: 아버지 개방1 2: 아버지 개방2 3: 어머니 개방1 4: 어머니 개방2 5: 미래확신성 6: 자기수용성 7: 친밀성 8: 주체성 9: 주도성 10: 목표지향성 11: 학교규범준수 12: 학교생활에 대한 흥미 13: 학업 및 성적에 대한 태도

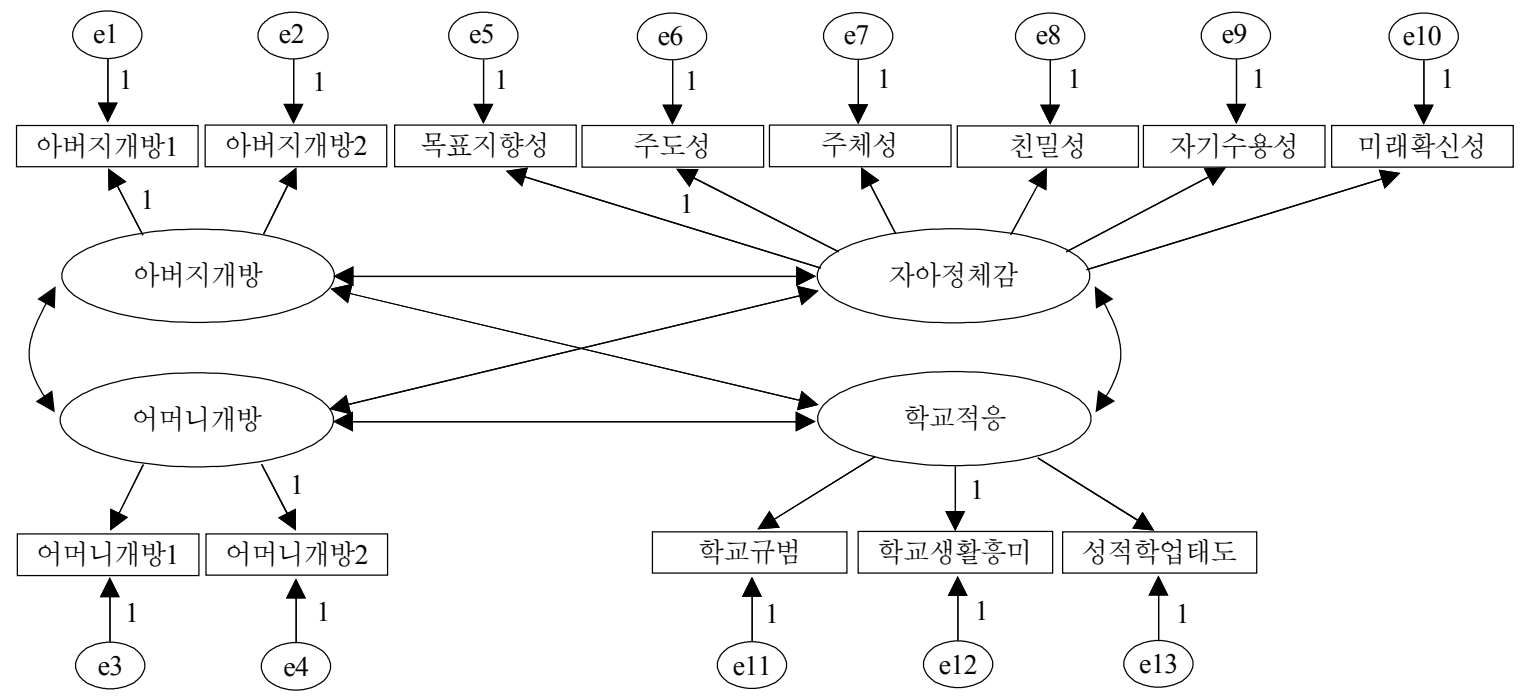

[그림 3] 측정모델

모델과 구조모델이 모두 모델추정가능성의 필요조건과 충분조건을 만족하는 것으로 나타남에 따라 측정모델의 부합도와 모수치를 추정하였다.

[그림 3]의 측정모델의 모델부합도를 알아보기 위해 최대우도추정법(ML)을 사용하여 모델부합도를 추정한 결과 <표 $3>$ 과 같다.

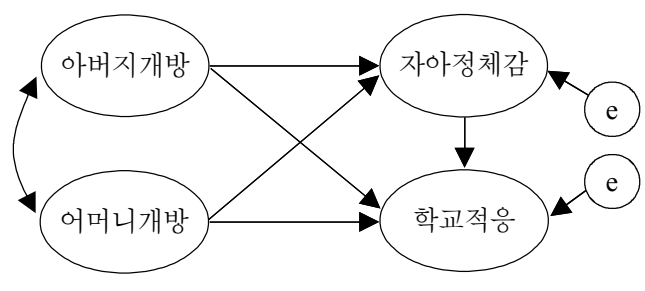

[그림 4] 구조모델 
<표 3> 측정모델 부합도 지수

\begin{tabular}{cccccccccc}
\hline \multirow{2}{*}{ 모델 } & \multirow{2}{*}{$\mathrm{NPAR}$} & \multirow{2}{*}{$\mathrm{DF}$} & $\mathrm{CMIN}$ & \multirow{2}{*}{$\mathrm{TLI}$} & \multirow{2}{*}{ SRMR } & \multirow{2}{*}{ CFI } & \multicolumn{2}{c}{ RMSEA } \\
\cline { 6 - 10 } & & & & & & & & LO90 & HI90 \\
\hline 측정모델 & 33 & 58 & 203.02 & .91 & .05 & .94 & .06 & .09 \\
\hline 기준 & & & $>.50$ & $>.90$ & $<.10$ & $>.90$ & $>.02$ & $<.10$ \\
\hline
\end{tabular}

일반적으로 SEM(Structural Equation Model) 연구의 부합도 분석 결과 보고는 최소한 1) 연구모델의 $\chi^{2}$ 값 (CIMIN), 2) Steiger-Lind의 90\% 신뢰구간 RMSEA, 3) Bentler의 CFI, Tucker와 Lewis(1973)의 TLI, 그리고 4) $\mathrm{SRMR}$ 을 보고할 것을 권장하고 있다(문수백, 2009). <표 $3>$ 에서 보는 것과 같이 부합도 지수평가에서 측정모델의 RMSEA(.06 .09)를 비롯한 모든 부합도지수가 부합도 기준에 양호하게 부합되는 것으로 나타났다.

\section{2) 구조모델의 부합도 추정결과}

측정모델의 모든 부합도지수가 부합도 기준을 충족시 키는 것으로 나타났으며 구조모델의 모델추정가능성이 이론적으로 확인되었기 때문에 최대우도추정방법을 통해 연구모델인 구조방정식 모델의 부합도를 추정한 결과는
<표 4>와 같다.

<표 4>에서 볼 수 있는 바와 같이, 초기 연구모델의 부합도를 추정한 결과 $\mathrm{RMSEA}(.06 \sim .09), \mathrm{CFI}=.94>.90$, $\mathrm{TLI}=.91>90$ 등 모든 부합도 지수 평가에서 부합도 기준 에 양호하게 부합되는 것으로 나타났다. 모델이 자료에 양호하게 부합되는 것으로 나타남에 따라 모델하의 모수치 들의 통계적 유의성을 검증한 결과는 <표 $5>$ 와 같다. <표 5>에서 볼 수 있는 것과 같이, 초기 구조방정식 모델 경로계수의 통계적 유의성 결과, 다른 변인들간의 관계는 모두 통계적으로 유의한 것으로 나타났으나 어머 니와의 개방형 의사소통이 학교적응에 미치는 직접효과가 통계적으로 유의하지 않는 것으로 나타났다(C.R.=.428, $p>01)$. 따라서 어머니와의 개방형 의사소통 $\rightarrow$ 학교적응 의 경로를 삭제시킨 보다 간명한 모델을 [그림 6]과 같이 <표 $4>$ 초기 구조방정식 모델의 부합도 지수

\begin{tabular}{|c|c|c|c|c|c|c|c|c|}
\hline \multirow{2}{*}{ 모델 } & \multirow{2}{*}{ NPAR } & \multirow{2}{*}{$\mathrm{DF}$} & \multirow{2}{*}{ CMIN } & \multirow{2}{*}{ TLI } & \multirow{2}{*}{ SRMR } & \multirow{2}{*}{$\mathrm{CFI}$} & \multicolumn{2}{|c|}{ RMSEA } \\
\hline & & & & & & & LO90 & HI90 \\
\hline 초기모델 & 33 & 58 & 203.02 & .91 & .05 & .94 & .06 & .09 \\
\hline 기준 & & & $>.50$ & $>.90$ & $<.10$ & $>.90$ & $>.02$ & $<.10$ \\
\hline
\end{tabular}

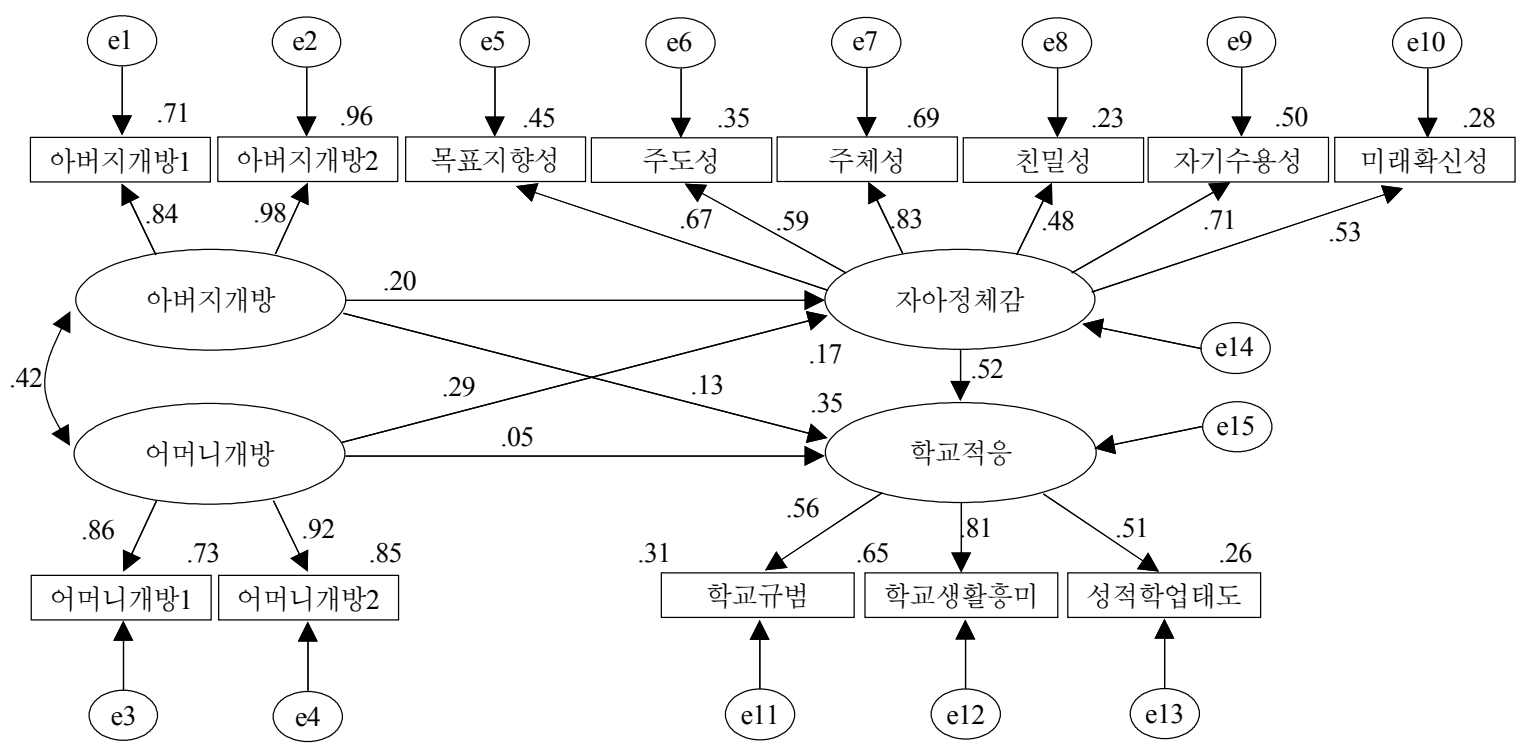

[그림 5] 초기 구조방정식 모델의 경로계수 
<표 5> 초기 구조방정식 모델의 모수치 추정 및 통계적 유의성 검증결과

\begin{tabular}{cccccc}
\hline 변인 & 비표준화계수 & $\mathrm{SE}$ & C.R. & $\mathrm{p}$ & 표준화계수 \\
\hline 자아정체감 $\leftarrow$ 아버지 개방 & .029 & .009 & 3.445 & $* *$ & .201 \\
\hline 자아정체감 $\leftarrow$ 어머니 개방 & .042 & .009 & 4.506 & $* *$ & .285 \\
\hline 학교적응 $\leftarrow$ 아버지 개방 & .017 & .01 & 2.138 & $*$ & .127 \\
\hline 학교적응 $\leftarrow$ 어머니 개방 & .007 & .01 & .793 & .428 & .050 \\
\hline 학교적응 $\leftarrow$ 자아정체감 & .468 & .06 & 7.290 & $* *$ & .516 \\
\hline
\end{tabular}

${ }^{*} p<.05, * * p<.01$

설정하였다.

\section{3) 모델의 수정 및 수정모델 분석}

수정된 구조방정식 모델의 부합도를 평가하기 위해 부 합도 지수를 추정한 결과 <표 6>과 같다.

위의 초기 구조방정식 모델과 수정 구조방정식 모델간 의 부합도 지수 비교에서 볼 수 있듯이, 전반적인 모델의 부합도 지수는 초기 구조방정식 모델과 비슷하였으나 절 대 부합지수인 $\chi^{2}$ 값(CMIN)만 0.62 만큼 높아진 것으로 나타났으나 통계적으로 유위할 만큼의 부합도가 나빠지 지 않은 것으로 나타나 수정된 구조방정식 모델의 모든
부합도 지수가 부합도 기준을 충족하는 것으로 나타났다. 학교적응에 영향을 미치는 각 변인들간의 직·간접 효과 를 분해한 결과는 <표 7>과 같다.

최종 구조방정식 모델의 전체효과, 직간접효과의 모수 치수를 통계적 방법에 따라 유의수준 .01에서 통계적 유 의성을 검증한 결과 첫째, 아버지와의 개방적 의사소통 은 자아정체감과 학교적응에 직접적인 효과를 미치는 것 으로 나타났으며 자아정체감을 통한 간접적 효과를 미치 는 것으로 나타났다. 둘째, 어머니와의 개방적 의사소통 은 자아정체감에 직접적인 효과를 미치며 학교적응에는 직접효과는 미치지 않고 자아정체감을 통한 간접적인 효

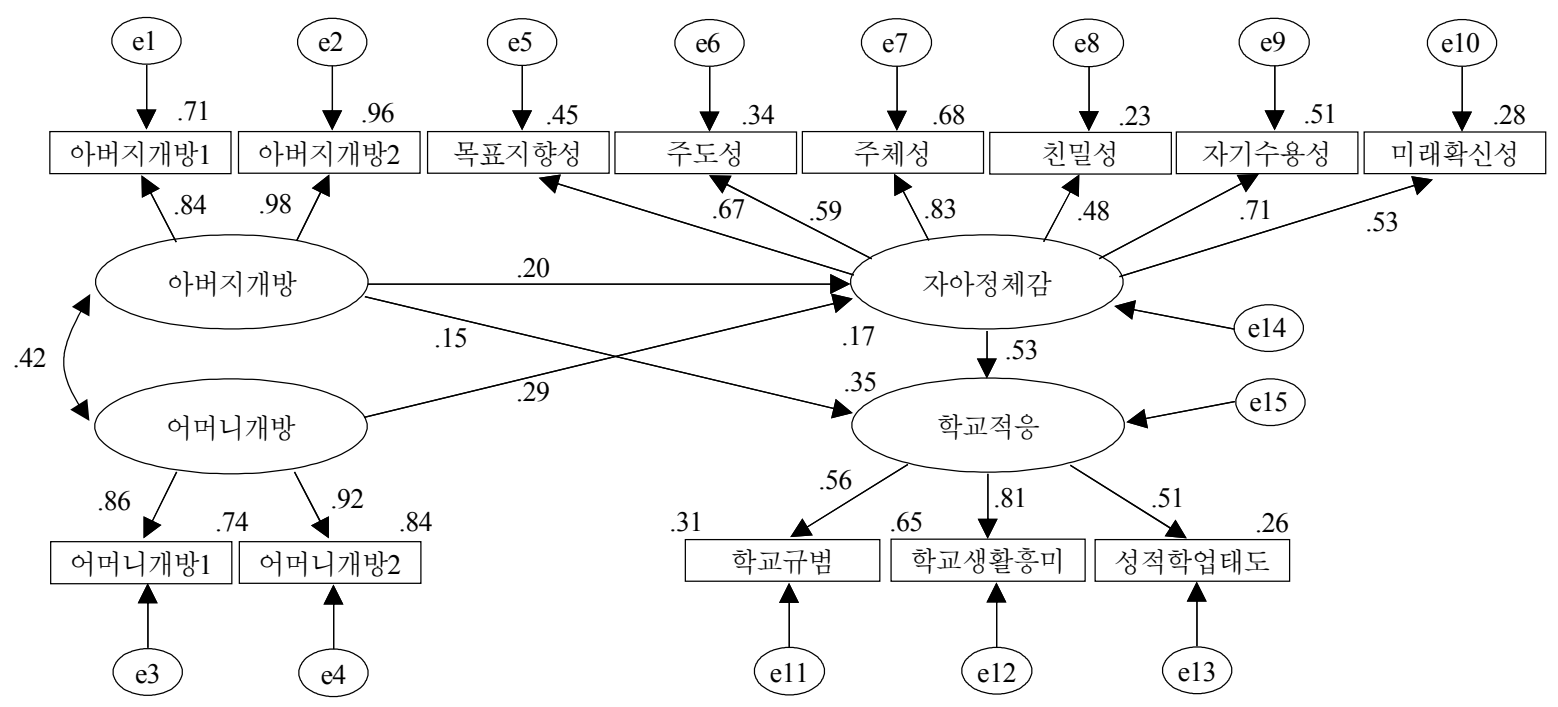

[그림 6] 수정 구조방정식 모델의 경로계수

<표 6> 수정된 구조방정식 모델의 부합도 지수

\begin{tabular}{cccccccccc}
\hline \multirow{2}{*}{ 모델 } & \multirow{2}{*}{$\mathrm{NPAR}$} & $\mathrm{NF}$ & $\mathrm{N}$ CMIN & \multirow{2}{*}{ TLI } & SRMR & \multirow{2}{*}{ CFI } & \multicolumn{2}{c}{ RMSEA } \\
\cline { 7 - 11 } & & & & & & & & LO90 & HI90 \\
\hline 수정모델 & 32 & 59 & 203.64 & .91 & .05 & .94 & .06 & .09 \\
\hline 초기모델 & 33 & 58 & 203.02 & .91 & .05 & .94 & .06 & .09 \\
\hline 기준 & & & $>.50$ & $>.90$ & $<.10$ & $>.90$ & $>.02$ & $<.10$ \\
\hline
\end{tabular}


<표 7> 학교적응에 대한 변인들의 직 · 간접 효과분해표

\begin{tabular}{cccc}
\hline 경로 & 전체효과 & 직접효과 & 간접효과 \\
\hline 아버지 개방 $\rightarrow$ 자아정체감 & .201 & $.201^{* *}$ & - \\
어머니 개방 $\rightarrow$ 자아정체감 & .291 & $.291^{* *}$ & - \\
아버지 개방 $\rightarrow$ 학교적응 & .252 & $.145^{* *}$ & $.107^{* *}$ \\
어머니 개방 $\rightarrow$ 학교적응 & .154 & - & $.154^{* *}$ \\
자아정체감 $\rightarrow$ 학교적응 & .531 & $.531^{* *}$ & - \\
\hline
\end{tabular}

과만을 미치는 것으로 나타났다. 셋째, 자아정체감은 학 교적응에 직접적인 영향을 미치는 것으로 나타났다.

3. 중학생, 고등학생 집단에서의 연구모형 동등성 검증

본 연구에서는 부모-자녀 간의 의사소통과 자아정체 감, 학교적응 간의 구조적 관계 연구모형이 중학생과 고등학생 집단에 동일하게 적용되는지를 확인하고자 하였다. 이를 위해 구조방정식에서 제공하는 다중집단 분석(multiple-group analysis)을 사용하였다. 이 방법 에서는 집단 간의 구조방정식 모델의 1) 측정계수모델 (measurement weight model)의 동일성을 검증, 2) 구 조계수모델(structural weights model)의 동일성 검증, 3) 구조공분산모델(structural covariance model)의 동 일성 검증, 4) 구조잔차모델(structural residual model) 의 동일성 검증으로 위계적으로 진행되었다(문수백,
2009). 이러한 위계적 검증은 순차적으로 하위모형에 내재되었기 때문이다.

<표 8>의 위계적 모델 간 부합도 비교검증 결과에서 볼 수 있는 바와 같이, 비제약모델(unconstrained model) 에서 중학생과 고등학생 집단 간에 구조방정식 모델의 요 인부하량을 동치로 제약한 측정계수모델의 부합도가 $\mathrm{CMIN}=8.23$ 정도로 나빠진 것으로 나타났으나 감소된 부 합도의 통계적 유의성을 검증한 결과 $p=51>.05$ 로서 통계 적으로 유의하지 않는 것으로 나타났다. 즉, 중학생과 고등 학생 집단 간에 구조방정식 모델 속의 측정모델 및 구조모 델의 형태가 같을 뿐만 아니라 측정모델의 요인부하량까 지도 같은 것으로 볼 수 있다.

중학생과 고등학생 집단 간의 측정계수모델의 동질성 이 인정됨에 따라 구조방정식 모델의 구조모델에 포함된 잠재변인들간의 관계를 나타내는 경로계수에 있어서도 동일한 것으로 볼 수 있는지를 검증하기 위해 중학생과 고등학생 집단간에 경로계수를 같은 값으로 제약한 구조 계수모델의 부합도를 검증한 결과, $\mathrm{CMIN}=10.79$ 로 2.56 정도 증가하여 부합도가 감소하였으며 $p=.03<05$ 로 통계 적으로 유의한 것으로 나타났다. 이는 중학생과 고등학생 집단 간에 경로계수까지는 같은 것으로 볼 수 없음을 보 여주며 더 이상이 분석이 필요 없음을 보여준다. 중학생 과 고등학생 집단의 학교적응에 영향을 미치는 각 변인들 간의 직 - 간접 효과를 분해한 결과는 <표 $9>$ 와 같다.

<표 8> 위계적 모델 비교검증 결과

\begin{tabular}{ccccccccc}
\hline 모델 & CMIN & DF & P & TLI & CFI & \multicolumn{2}{c}{ RMSEA } \\
\cline { 6 - 9 } & & & .51 & .91 & .92 & LO90 & HI90 \\
\hline 측정계수모델 & 8.23 & 9 & .03 & .91 & .92 & .05 & .07 \\
\hline 구조계수모델 & 10.79 & 4 & .48 & .91 & .92 & .05 & .07 \\
\hline 구조공분산모델 & 2.45 & 3 & .17 & .91 & .92 & .05 & .07 \\
\hline 구조잔차모델 & 3.56 & 2 & &
\end{tabular}

<표 9> 중학생과 고등학생의 변인들에 대한 효과분해표

\begin{tabular}{ccccccc}
\hline \multirow{2}{*}{ 경로 } & \multicolumn{3}{c}{ 중학생 } & \multicolumn{3}{c}{ 고등학생 } \\
\cline { 2 - 7 } & 전체효과 & 직접효과 & 간접효과 & 전체효과 & 직접효과 & 간접효과 \\
\hline 아버지 개방 $\rightarrow$ 자아정체감 & .205 & $.205^{* *}$ & - & .175 & $.175^{* *}$ & - \\
어머니 개방 $\rightarrow$ 자아정체감 & .401 & $.401^{* *}$ & - & .187 & $.187^{* *}$ & - \\
아버지 개방 $\rightarrow$ 학교적응 & .314 & $.197^{* *}$ & $.117^{* *}$ & .191 & $.095^{*}$ & $.096^{*}$ \\
어머니 개방 $\rightarrow$ 학교적응 & .229 & - & $.229^{* *}$ & .102 & - & $.102^{* *}$ \\
자아정체감 $\rightarrow$ 학교적응 & .570 & $.570^{* *}$ & - & .547 & $.547^{* *}$ & - \\
\hline
\end{tabular}




\section{$\mathrm{IV}$. 논의 및 결론}

본 연구에서는 중, 고등학교 청소년을 대상으로 아버 지와의 개방적 의사소통과 어머니와의 개방적 의사소통, 자아정체감이 학교적응에 미치는 직·간접효과를 알아 보기 위해 구조방정식 모형을 설정하여 측정모델과 구조 모델로 나누어 모델의 부합여부와 경로계수의 효과를 검 증하였다. 또한 본 연구를 통해 채택된 구조방정식 모델 이 중학생과 고등학생 집단에 동일하게 적용될 수 있는 지를 살펴보았다. 본 연구의 결과를 토대로 논의하면 다 음과 같다.

첫째, 부모-자녀간의 개방적 의사소통이 학교적응에 미치는 영향에 대해 살펴본 결과 청소년들은 아버지와 개방적 의사소통을 할수록 학교생활에 더 잘 적응하는 것으로 나타났다. 자녀양육에 있어 아버지는 어머니와는 다소 다른 역할을 제공한다. 어머니는 표현적이고 정서 적인 역할을 제공하는 반면, 아버지는 도구적이고 이성 적이며 판단자의 역할을 제공한다. 특히 자녀가 청소년 기에 이르렀을 때에는 아버지는 자녀의 직업관과 직업 선택의 보조자 역할을 하게 되며 아버지의 이러한 역할 은 자녀에게 포부와 성취동기를 부여하는데 결정적인 역 할을 한다. 또한 청소년기 동안 아버지의 격려와 지지는 자녀의 지적 발달과 동기발달에 영향을 미치며 자녀의 학업 성취와 태도에 중요한 영향을 미치게 된다. 미래의 직업적 성취와 적응에 초석이 될 수 있는 학교생활에 대 해 아버지가 청소년들과 개방적이고 수용적으로 의사소 통할 경우 청소년들은 학교생활의 중요성에 대한 인식하 게 되고 학교생활에 잘 적응하기 위해 더 노력하게 되리 라 생각되어진다. 본 연구의 결과는 아버지와의 의사소 통이 개방적일수록 학교 수업에 적극적으로 참여한다고 보고한 백경숙, 권용신(2004)의 연구와 아버지와의 개방 형 의사소통이 학업 성취도뿐 아니라 전체 학교적응에 영향을 미친다고 보고한 남민숙(2006)의 연구와 그 맥을 같이 한다. 이러한 결과를 통해 아버지와의 의사소통이 청소년들의 학교적응에 중요한 변인임을 알 수 있었으며 앞으로는 아버지와 청소년 자녀들간의 친밀하고 개방적 인 의사소통을 촉진하기 위한 다양한 방안이 모색되어야 할 것으로 생각되어진다.

반면, 어머니와의 개방형 의사소통은 학교적응에 직접 적인 영향은 미치지 않았으나 자아정체감을 통해 간접적 인 영향을 미치는 것으로 나타났다. 이러한 결과는 어머 니와 개방적인 의사소통이 아동의 학교적응에는 유의미
한 영향을 미친다는 이경님(2003), 홍연란(2000)의 연구 와는 다소 다른 결과이나 청소년의 학교적응이나 비행에 미치는 상대적 영향력이 유의미하지 않다고 보고한 이경 님, 하연미(2004), 이진숙, 정혜정(2004), 조윤미, 이숙 (2008)의 연구와 부분적으로 일치한다. 이러한 결과는 자녀가 초등학생일 때에는 어머니와의 개방적 의사소통 이 학교적응에 직접적인 영향을 미치지만 중, 고등학생 이 되어서는 학교적응에 직접적인 영향을 미치기보다는 제 3의 변인을 통해 간접적인 영향을 미치기 때문이라 생각된다.

둘째, 부모-자녀간의 의사소통은 자아정체감을 통해 간접적으로도 청소년의 학교적응에 영향을 미치는 것으 로 나타났다. 청소년의 자아정체감은 아버지, 어머니와 개방적인 의사소통을 할수록 높은 것으로 나타났다. 부 모와의 개방적이고 수용적인 대화를 통해 청소년들은 자 신의 존재에 대해 확신을 얻고 자신이 앞으로 나아가야 할 방향과 목표를 설정하게 되며 더 나아가 자신이 속한 학교환경에 잘 적응하는 것으로 보여진다. 부모-자녀간의 의사소통이 자아정체감을 통해 간접적인 영향을 미친다 는 본 연구의 결과는 부모와의 의사소통이나 양육행동이 청소년의 자아관련 변인을 통해 학교적응에 간접적인 영 향을 미친다고 보고한 민하영, 권기남(2004), 백경미 외 (2008), 신현숙, 임말란(2005) 등의 연구 결과와 그 맥을 같이 한다. 자녀가 청소년기에 접어들면서 또래와 보내 는 시간은 많아지는 반면, 부모와 함께 보내는 시간이 줄 어들며 의사소통의 기회와 시간이 감소되는 경향이 있다. 그러나 부모-자녀간의 의사소통이 청소년의 긍정적인 발 달과 적응에 중요함을 생각할 때 부모들은 학교생활이나 적응에 대해 자녀와 직접적으로 의사소통할 뿐 아니라 자아정체감을 항상시키거나 자아에 관련된 변인을 다룸 으로써 청소년들의 학교적응을 향상시키기 위한 노력을 해야 할 것으로 생각되어진다.

셋째, 자아정체감은 학교적응에 가장 큰 직접적인 영 향을 미치는 것으로 나타났으며 이는 청소년의 자아정체 감이 높을수록 학교에 잘 적응하는 것을 의미한다. 자신 이 누구인지를 알고 자신을 있는 그대로 수용하며 삶에 있어 자신이 주인이며 자신의 노력에 따라 미래가 바뀔 수 있다고 생각할수록 청소년들은 자신이 속한 집단, 특 히 학교 환경에 잘 적응하고 흥미를 느끼며 청소년기의 중요한 과업인 학업과 성적에 최선을 다할 것으로 생각 되어진다. 또한 긍정적인 자아정체감을 형성한 청소년들 은 타인과 친밀한 관계를 형성하며 또래와 교사 등을 비 
롯한 대인관계에서 안정적인 적응을 이루게 된다. 반면, 부정적인 자아정체감을 형성하거나 정체감 혼미에 빠지 게 되는 경우 자기를 부정하고 무능한 존재로 열등시 하 며 미래에 대한 방향성을 상실하고 자기 혼란에 빠지게 된다. 이러한 청소년들은 학교 현장에서 흥미와 의욕을 상실하고 잘 적응하지 못하며 비행이나 일탈된 행동을 하게 되는 경우가 많다. 청소년들의 중요한 발달과업이 자아정체감 형성인 만큼 청소년들의 긍정적인 자아정체 감을 형성하도록 하는 효과적인 개입이 이루어지는 것이 바람직할 것으로 생각되어지며 이는 곧 학교적응에 긍정 적인 영향을 미칠 것으로 생각되어진다. 본 연구의 결과 는 청소년들의 자아정체감이 학교적응에 중요한 영향을 미친다고 보고한 박영란(2002), 현희순과 김양순(1999) 등의 연구들과 부분적으로 일치한다.

넷째, 본 연구에서 채택된 연구모형이 중학생과 고등 학생에게 동일하게 적용될 수 있는지에 대해 살펴본 결 과 두 집단에게 동일한 모형을 적용할 수 있으나 두 집단 간의 경로계수에는 차이가 있는 것으로 나타났다. 중학 생 집단은 아버지와 어머니와의 개방적 의사소통이 자아 정체감과 학교적응에 미치는 전체효과와 자아정체감이 학교적응에 미치는 전체효과 모두에서 고등학생보다 효 과가 큰 것으로 나타났다. 이는 청소년의 연령에 따라 부 모와의 개방적인 의사소통과 자아정체감이 청소년의 발 달과 적응에 미치는 영향에 차이가 있음을 보여주는 결 과이며 중학생일수록 이들 변인들이 학교적응에 미치는 영향력이 크다는 것을 보여주는 결과라 할 수 있다.

이러한 논의를 통하여 다음과 같은 결론을 내릴 수 있 다. 첫째, 부모-자녀 간의 개방적인 의사소통은 청소년의 학교적응에 직 - 간접적으로 영향을 미치는 중요한 요인 이다. 둘째, 자아정체감은 학교적응에 직접적으로 영향을 미치는 중요한 요인이며 부모-자녀간의 의사소통이 학교 적응에 미치는 영향을 매개하는 요인으로 작용한다. 셋 째, 부모-자녀 간의 의사소통과 자아정체감이 학교적응에 미치는 영향은 중학생과 고등학생에 따라 다소 차이가 있는 것으로 나타났다.

본 연구는 구조방정식 모델을 통해 부모-자녀 간의 의 사소통, 자아정체감, 청소년의 학교적응 간의 구조적 관 계를 살펴봄으로써 부모-자녀 간의 의사소통이 학교적응 에 미치는 직접적인 효과뿐만 아니라 자아정체감을 통한 간접적인 효과를 확인했다는 점에서 의의가 있다. 또한 본 연구를 통해 확인된 구조적 관계가 중학생과 고등학 생에 따라 차이가 있는지를 살펴본 결과 학교적응을 향
상시키기 위한 노력이 청소년의 발달단계에 따라 차별화 되어야 함을 밝혔다는 점에서 그 의의가 있다.

이상과 같은 결론을 통해 후속연구를 위해 몇 가지 제 언을 하고자 한다. 첫째, 본 연구에서는 청소년의 학교적 응에 영향을 미치는 요인으로 부모-자녀 간의 의사소통 과 자아정체감만을 포함하였으나 앞으로의 연구에서는 좀 더 다양한 변인들을 고려하여 변인들 간의 구조적 관 계를 파악하는 연구가 이루어지는 것이 필요하다. 둘째, 본 연구에서는 청소년의 자기 보고식 설문을 통해 학교 적응을 평가하였으나 앞으로의 연구에서는 면접 등의 다 양한 방법과 부모의 평가나 교사의 평가 등 다양한 보고 자의 평가를 바탕으로 연구가 이루어지는 것도 의미가 있을 것이다.

주제어 : 청소년, 아버지와의 의사소통, 어머니와의 의 사소통, 자아정체감, 학교적응

\section{참 고 문 헌}

교육부. (2006), 교육통계연보. 교육부.

구자경, 장유진, 홍지영. (2001). 학교를 떠나려는 아이들에 대한 이해와 상담 전략. 서울청소년상담연구, 7 , $5-54$.

김광수. (2002). 청소년의 학교생활적응 현황과 지도방안. 교육논총, 17(1), 1-15.

김수진, 이정숙, 최봉실. (2004). 지역사회 청소년 정신 보건 사업 모형 개발을 위한 학교적응 유연성 영향요인 연구. 정신간호학회지, 13(3), 291-303.

김여진. (2006). 청소년이 지각한 부모와의 의사소통과 스트 레스 대처방식 및 학교적응간의 관계. 서울여자대학 교 석사학위논문.

김지현. (1995). 서울지역 중학교 학생의 가정환경과 학교적 응의 관계 연구. 숙명여자대학교 석사학위논문.

남민숙. (2006). 아동이 지각한 부모-자녀간의 의사소통유형 과 학교적응의 관계. 춘천교육대학교 교육대학원 석 사학위논문.

류경희. (2003). 청소년의 학교생활 부적응에 영향을 미치는 가족관련 변인. 대한가정학회지, 41(12), 147-168. 문수백. (2009). 구조방정식 모델링의 이해와 적용. 학지사.

문영숙. (2008). 부모-자녀 의사소통이 청소년의 자아개념, 문제행동에 미치는 영향. 아동간호학회지, 14(4), 405-414. 
문은식. (2002). 청소년의 학교생활 적응행동에 관련되는 사 회심리적 변인들의 구조적 분석. 충남대학교 박사학 위논문.

민하영, 권기남. (2004). 저소득층 아동의 학교 적응: 아동이 지각한 부모의 양육행동과 아동의 자아정체감을 중 심으로. 아동학회지, 25(2), 81-92.

민혜영. (1990). Circumplex Model과 부모-자녀간의 의사소 통 : 청소년 자녀를 중심으로. 연세대학교 석사학위 논문.

박아청. (1996), 한국형 자아정체감 검사 개발에 관한 연구. 한국심리학회지, 15(1), 140-162.

박영란. (2002). 중학생의 자아정체감과 학교 적응 및 학업 성취도와의 관계. 동국대학교 교육대학원 석사학위 논문.

박지현. (2003). 청소년과 부모와의 관계가 학교적응에 미치 는 영향. 한남대학교 석사학위논문.

박현선. (1998). 빈곤청소년의 학교적응 유연성. 서울대학교 박사학위논문.

배숙진. (1998). 청소년에게 지각된 부모의 양육태도, 자아 개념, 학교적응간의 관계. 연세대학교 석사학위논 문.

백경미, 현성용, 한영숙. (2008). 부모-자녀 간 의사소통과 자기효능감이 학교적응에 미치는 영향. 2008 한국 심리학회 연차학술발표대회 논문집, 666-667.

백경숙, 권용신. (2004). 부모-자녀간 의사소통유형이 청소 년자녀의 학교생활적응에 미치는 영향. 청소년복지 연구, 6(2) 87-99.

신현숙, 임말란. (2005). 청소년의 부모애착과 학교적응의 관계에서 수평적 대인관계 성향의 매개효과. 청소년 학 연구, 12(1), 103-126.

유윤희. (1994), 학교적응 - 불안 - 학업성취간의 관계분석. 고려대학교 석사학위논문.

이경님. (2003). 아동이 지각한 어머니와의 의사소통과 자아 존중감이 학교적응에 미치는 영향. 생활과학연구 논 문집, 11, 197-214.

이경님, 하연미. (2004). 청소년의 인터넷비행과 관련변인간 의 경로분석모델. 대한가정학회지, 42(5), 127-143.

이승국. (1999). 청소년의 자아정체감 발달에 영향을 미치는 생태학적 변인들의 구조 분석. 계명대학교 박사학위 논문.

이종연, 이재신. (2000). 괴롭힘 경험을 가진 학생들의 자아 정체감, 사회적지지 및 학교생활 적응의 관계. 교육 연구논총, $4,47-75$.

이진숙, 정혜정. (2004). 청소년 자녀가 지각한 부모의 부부
관계 및 부모에 대한 애착과 학교적응의 관계. 한국 가정관리학회지, 22(3), 47-. 61.

이현림, 천미숙. (2003). 청소년의 자아정체감과 학교생활적 응 간의 관계분석. 청소년학연구, 10(4), 511-514.

정유진. (1999). 청소년 학교생활 적응의 관련 변인. 연세대 학교 석사학위논문.

조미란. (1989). 중고등학교 학생의 자아정체감 발달과 학업 성취와의 관계 연구. 충북대학교 석사학위논문. 조윤미, 이숙. (2008). 중학생의 부모-자녀 의사소통과 자기 효능감이 학교생활적응에 미치는 영향. 한국지역사 회생활과학회지, 19(4), 641-658.

최재숙. (2001). 초등학생 자녀의 부모와의 의사소통 유형과 학교생활 적응과의 관계. 한남대학교 교육대학원 석 사학위논문

현희순, 김양순. (1999). 청소년의 자아정체감 발달과 가정 생활 및 학교생활 적응에 관한 연구. 아동학회지, 20(1), 249-262.

홍연란. (2000). 초등학생의 스트레스요인, 대처방식, 어머 니와의 의사소통 및 학교 적응. 아동간호학회지, 6(3), 362-371.

Armsden, G. C., \& Greenberg, M. T. (1987). The inventory of parent and peer atachment: Individual differences and their relationship to psychological well-being in adolescence. Journal of Youth and Adolescence, 16(5), 427-453.

Barnes, H. L., \& Olson, D. H. (1982). Parent-adolescent Communication Family Inventories. In Olson, D. H., McCubbin, H.I., Barnes, H. L., Larsen, A., S., Muxen, M. J., Wilson, M. A.(Eds.)(1983). Families: What Makes Them Work. Beverly Hills, Califormia: Sage

Collins, W. A., \& Repinski, D. J. (1994). Relationships during adolescence: Continuity and change in interpersonal perspective. In R. Montemayor, \& G. R. Adams(Eds.), Advances in Adolescent Development: An Annual Book Series, 6, 7-36.

Erath, S. A., Flanagan, K. S., \& Bierman, K. L. (2008). Early adolescent school adjustment: Associations with friendship and peer victimization. Social Development, 17(4), 853-870.

Erikson, E. H. (1968). Identity: Youth and Crisis, New York: Norton \& Co.

Hill, J. P., \& Holmbeck, G. N. (1986). Attachment and autonomy during adolescence. Annals of Child 
Development, 3, 145-189.

Kurdek, L. A., \& Sinclair, R. J. (1988). Relation of eight graders' family structure, gender, and family environment with academic performance. Journal of Educational Psychology, 80(1), 90-94.

접 수 일

2009. 07. 15.

수정완료일 